\title{
Licking the Body in Ancient Egyptian Funerary Texts
}

\author{
Eltayeb Abbas and Youssri Abdelwahed
}

\section{Faculty of Tourism and Hotels, Minia University}

\begin{abstract}
In ancient Egyptian funerary texts, the licking of the body occurs in two different contexts. The first occurs in the course of mummification where the deceased's body is said to be licked by a goddess or the son of the deceased. The second context occurs when the deceased is frightened that his body is licked by a monster in his journey to the underworld. The aim of this paper is to deal with these two different contexts using evidence from the Pyramid Texts, Coffin Texts, New Kingdom Coffin inscriptions and Late Period Papyri.
\end{abstract}

\section{Key Words}

Licking, Funerary Texts, Healing Power, Punishment, Saliva, Judgment, Sinners, Licking a Spell, Dog, Neith

The licking of the body occurs in two different contexts in ancient Egyptian funerary texts. In the first context, the licking of the body is envisaged as having a healing power that restores the body of the deceased who has been collapsed at death. This healing power is envisaged in the saliva that comes out from the mouth of the deity when the body of the deceased is licked. It represents the power of rebirth. In the second context, the licking of the body is a punishment for the sinners. The deceased is frightened that his body is licked by a monster in the course of the Judgment of the Dead. These two different contexts will be dealt with in the following pages. 


\section{The Licking of the Body as a Healing and Curative Power}

The licking of the body occurs on the lid of the Sarcophagus of King Merenptah. On this sarcophagus, the goddess Neith speaks to the king in a long speech acting as his mother and protector. ${ }^{\mathrm{i}}$ The goddess Neith, as personification of the coffin, plays the role of the sky goddess Nut. ${ }^{\mathrm{ii}}$ The speech of the goddess deals with nightly ritual taking place around the bier of the deceased king. These rituals are known as the Stundenwachen in which ritual texts are recited on the body of the deceased king during the night before burial. It was a wake in the place of embalming where the recitation around the bier of the deceased Osiris takes place. It is also a vigil conducted over the corpse of Osiris that was later on adapted for the benefit of the dead humans. ${ }^{\text {iii }}$

The speech of Neith on the outer coffin of Merenptahis is a liturgy recited by a priestess playing the role of the goddess and acts as the mother of the deceased. The long speech of the goddess resembles the liturgy of Coffin Texts Spell 62 which occurs on the Middle Kingdom coffin of the nomarch Amenmhat. ${ }^{\text {iv }}$ It is also modeled on the New Kingdom liturgies in the Book of the Dead Chapters 151and 169. The nightly rituals around the bier of Osiris within the speech of the goddess focus on the reintegration of the dismembered body of the dead king, his protection and justification in the tribunal of Osiris. ${ }^{\mathrm{v}}$ It is a wake in the place of embalming and aims at the restoration, the justification and the protection of the deceased Osiris. ${ }^{\mathrm{vi}}$

It is not my aim here to deal with the whole liturgy that occurs on the coffin, but with specific passages. The text on the coffin of Merenptah can be divided into stanzas. In one of these stanzas, the goddess says:

jnk mwt=k Att nfrw=k I am your mother who nurses your beauty. $\mathrm{jwr}=\mathrm{j} \mathrm{jm}=\mathrm{k}$ tp dwAjjt I am pregnant with you in the morning, $s m s j=j$ tw $m$ Ra $m$ and deliver you as Re in the evening, mSrw

hnhn=j tw jw=k Hr I carry you, you being on my back. $\mathrm{sA}=\mathrm{j}$

$w T s=j \quad s a H=k \quad a w j=j \quad$ I elevate your mummy, my arms under you. $\mathrm{xr}=\mathrm{k}$

$\mathrm{Xnm}=\mathrm{j} n \mathrm{nfw}=\mathrm{k}$ At $\mathrm{r}$ At I continually take your beauty into myself, $\mathrm{aq}=\mathrm{k} \quad \mathrm{jm}=\mathrm{j} \quad \mathrm{qnj}=\mathrm{j}$ When you enter into me, I embrace your 
$\mathrm{sSmw}=\mathrm{k}$

mwt $=\mathrm{k} \quad \mathrm{jm}=\mathrm{j} \quad \mathrm{hApt}=\mathrm{s}$ $\mathrm{bs}=\mathrm{k}$ image.

I am your mother/coffin that shelters your mysterious shape. ${ }^{\text {vii }}$

In this stanza, the goddess Neith speaks to the deceased king Merenptah who is placed within the coffin. She is acting as the sky goddess Nut who gives birth to king in the morning to become Re. This type of speeches, where Nut speaks to the deceased as an embodiment of the coffin and mother, is common on all coffins from

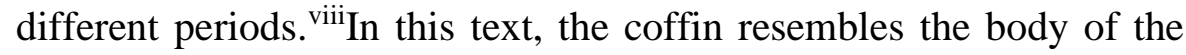
sky goddess which encloses the divine realm where the deceased king is. The coffin, which is the body of the goddess, is the house of the deceased king who is embraced by the goddess when he enters into it. She is the coffin itself that houses the mysterious shape of the deceased king. The goddess says also that she is carrying the king on her back in his journey across the sky and elevates him with her arms. She is the divine space that resembles the whole cosmos of the deceased king. At the end of the stanza, the goddess identifies herself with the coffin that houses the body of the king. The next stanza reads:

$\mathrm{jb}=\mathrm{j}$ Hna $=\mathrm{k}$ m-jmjt $\mathrm{pr}=\mathrm{k}$

$\mathrm{sDd}=\mathrm{f} \mathrm{n}=\mathrm{k}$ m xntj hnw nwt

$r A=j$ spdw Hr sAxt $b A=k$

$\mathrm{HkAw}=\mathrm{j} \mathrm{m}$ sAw awt=k

$d j=j n=k$ a $=j$

prj=k r Hrt

xaywj tw $\mathrm{m}$ jmjtw wartj $=\mathrm{j}$

jrj=k aHaw $m$ jmjtw $a b w y=j$

$\mathrm{jmH}=\mathrm{k} \mathrm{jm}=\mathrm{j} \mathrm{nsb}=\mathrm{j}$ Haw $=\mathrm{k}$

$\mathrm{jrj}=\mathrm{j} w \mathrm{wabw}=\mathrm{k} \mathrm{m}$ fdt $\mathrm{Haw}=\mathrm{j}$

nma=k tw Hr nnmt jmjt=j

$j r j=j n=k$ Hrt $m$ jmjt=j

$\mathrm{Hr} n=\mathrm{k} m$ psD $=\mathrm{j}$

$\mathrm{jrj}=\mathrm{j} n=k$ sATw $m \mathrm{Xt}=\mathrm{j}$
My heart is with you as your house (shelter).

He speaks to you as the one in front of the coffin of Nut,

My mouth is sharp in glorifying your $\mathrm{Ba}$,

and my magical powers are in the protection of your limbs,

I give to you my arm, so that you may ascend to the sky, and rises between my feet, and stands between my horns.

When you drink from me (drink the milk), I shall lick your limbs (body)

and do your cleansing with the sweat of my limbs.

When you place yourself on the bier which is like me.

I will be like the heaven for you, when you are on my back, My belly will be the ground (floor) for 
you. ${ }^{\text {ix }}$

In this stanza the goddess identifies her heart with the house of the deceased. Here the king's body is identified with the different parts of the goddess. The heart will be the eternal house of Merenptah and will be speaking to the king as the one who stands in front of the coffin of Nut. After that comes the role of the spoken word in the glorification of the bA of the deceased king. The goddess plays here the role of the ritaulist who will be reciting glorification spells on the body of the deceased king in the night before burial; the Stundenwachen. The role of the spoken word by the goddess is important here. This part of the text deals with the healing of the social isolation of the king and his reintegration into the community of the gods in the underworld. ${ }^{\mathrm{x}}$ This is done in the form of recitation in the night before burial. Merenptah, who has been isolated at death, will be reintegrated in the underworld with the community of the gods and becomes an Ax, by the power of the speech of the goddess who is glorifying the king's bA. The king will be protected also by the magical powers of the goddess who will be watching over every limb of the deceased king.

Neith also assumes the roles of different goddesses. She is Nut who elevates the deceased king to the sky between her two arms. She is also Hathor who places the king between her two horns in his journey across the sky. She is acting as the mother of the deceased king, where she feeds him with her milk playing the role of the cow with her young calf. The image here is of a cow licking the body of young calf while feeding him with her milk. The feeding of the young calf is accompanied by cleansing of its body by the saliva that comes out from the mouth of its mother.

The licking of the body of Merenptah by the saliva that comes out from the mouth and tongue of the goddess Neith aims to restore the body of the deceased king. The licking has a healing power as it is the divine saliva that comes from the mouth of the goddess. Just as offering, the licking of the body restores something that has been lost at death. In the Pyramid Texts Spell 166, the deceased's offerings of two Zizyphus bowls are described as the Eye of Horus that has been licked by the gods.

The text reads:

Wsjr NN m-n=k jrt Hrw Oh Osiris NN, take for yourself nsbt.n=sn the Eye of Horus, which they have 
licked.

Dd mdw zp $4 \mathrm{n}$ NN pn fAt Hnqt Recitations 4 times for this NN zp 4 nbs 2 two ziziphus bowls two times. ${ }^{\mathrm{xi}}$

The texts can be interpreted as follows; the Eye of Horus that has been injured by Seth has then been licked and healed by the gods and presented to the deceased king in the form of two Zizphus bowls. The offering of the Eye of Horus is the cultic expression of every item to be offered. It shows also that when an item is offered as the Eye of Horus that simply means, in Assmann's words, that 'it will restore something that has been destroyed or used up, put together something that has fallen apart, or replace something that has been lost. It is the symbol of reversibility. ${ }^{\text {xii }}$ This also means that when the body of the deceased king Merenptah is licked by the goddess Neith, it will be restored and be healed from its injuries that have been caused by death. The licking of the body is also accompanied by the recitation of the glorification spells by the goddess Neith on the body of the king Merenptah.

The licking of the body of the king Merenptah by the goddess Neith recalls the well-known role of the goddess Hathor as a mother licking the body of her young calf. This role of Hathor is well attested in texts and iconography from different periods. She is the one who licks and kisses the hand of Hatshepsut in her temple at Deir ElBahri, where Hathor addresses Hatshepsut saying:

sn a $(\mathrm{t})$ nsb Haw

Xnm Hmt=T m anx wAs
Kissing the hand, licking the limbs, And endowing your majesty with life and dominion. ${ }^{\text {xiii }}$

In this scene Queen Hatshepsut is represented sitting on her throne extending her hand to Hathor who licks it (Fig. 1). The licking here endows Queen Hatshepsut with life and dominion. It is a symbol of rebirth, which is also confirmed by another text on the walls of her temple. Thutmosis III is said to be Horus who has been licked by the goddess Hathor whom she has borne. ${ }^{\text {xiv }}$

In the funerary context, the licking of the deceased king Merenptah by the goddess Neith's tongue resembles the cleansing of his body during mummification. The saliva that comes out from the mouth of Neith resembles the water that is poured on the body of the king during purification, which is an episode in the bigger ritual of 
the mummification of the deceased's body. This is also reinforced by the fact that the goddess's body will be the bier of the king on which he is placed in his journey across the sky. Neith plays here the role of Nut in whose body King Merenptah ferries across the sky.

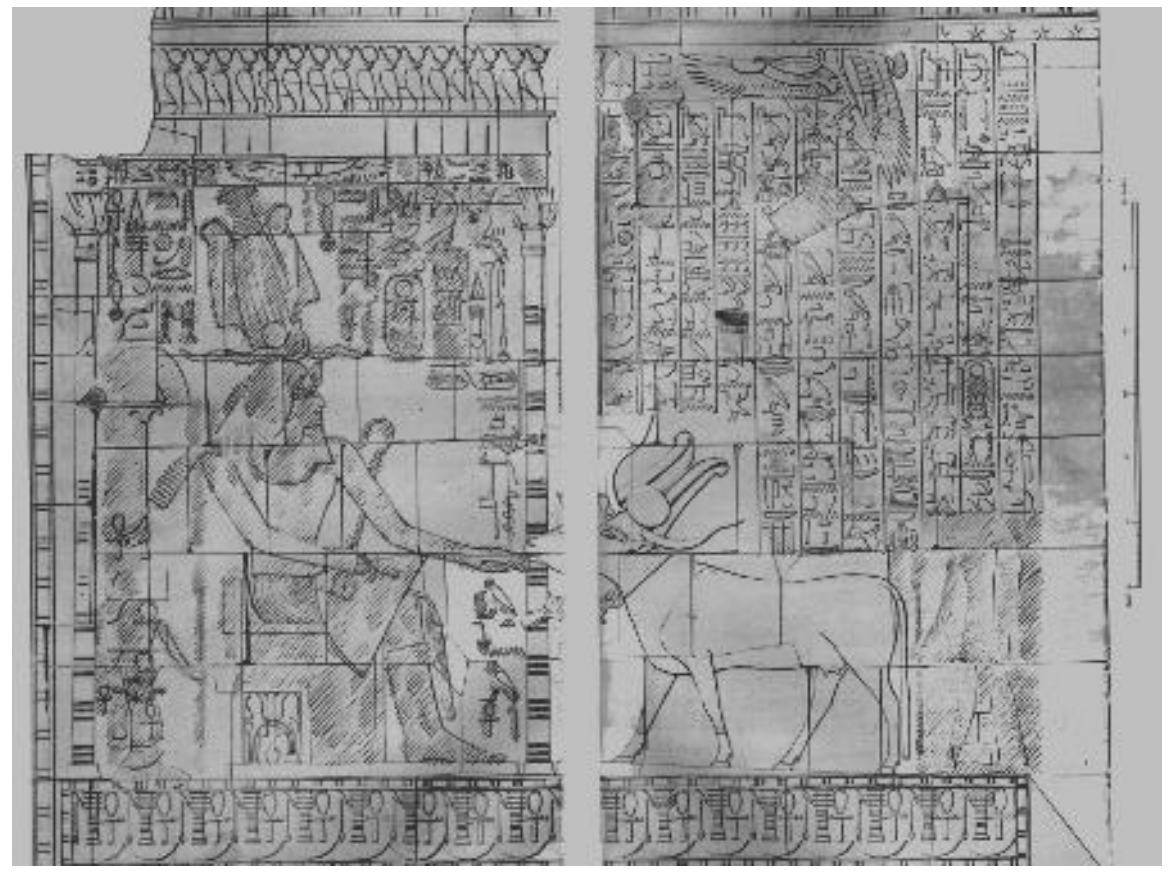

Fig. I. The Goddess Hathor licks the hand of Queen Hatshepsut (After, Naville 1901: Pl. XCIV).

The licking of the king's body by the goddess is a blessing. The connection between licking, being elevated to the sky and the sun rise, as indication for the elevation of the deceased king, is well expressed in Coffin Texts Spell 1053. The spell reads:

rA n swA Hr=s nw ntj tpawj

rA n swA $\mathrm{Hr}=\mathrm{s}$ wAwt

njwwt ds hAw-xrw

wAt snw m xrw

$\mathrm{jm}=\mathrm{k}$ swA jm=s

rA n swA Hr wAwt sDt

$\mathrm{N}$ jrt Hr

jrt tw sAb m sDt nfrw=s
A spell for passing over it (the Lake of Fire) which is before me.

A spell for passing by the Abode of the Knife-Wielders and of those who shout. This is the lower path, You should not pass on it.

A spell for passing the path of fire,

$\mathrm{N}$ is the Eye of Horus,

Beneficial in the night, which makes 
fire with its beauty,

$\mathrm{N} n b$ Axt psD xpr nsb=f wj $\mathrm{N}$ is the Lord of the horizon. When Khepri shines, he licks me. ${ }^{\mathrm{xv}}$

Here the licking and the early appearance in the horizon is well expressed. This might also reinforce the association of the licking of Merenptah's body and his journey across the sky. The elevation of the deceased king in the body of the goddess is an indication of his resurrection from death which is also connected with the sunrise.

The journey of the deceased king who is placed on a bier at the night before burial is ready to start the next day. The journey from death to resurrection resembles the journey of the sun god Re across the sky. Merenptah, who has already been mummified and rituals on his body have been concluded at the night before burial in the form of the Stundewachen, will start his journey the next day to the necropolis. The path or route of the journey of the deceased king Merenptah to the necropolis in the body of Neith is the same path of the sun god Re in body of the sky goddess Nut across the sky. Neith continues her speech to king Merenptah saying:

jmjw nwt=j $m$ nTrw $m$ My inhabitants of Nut are your $\mathrm{sAw}=\mathrm{k}$

ggtj $=j n=k$ m sntj protective gods.

r jrjt sAw=k m HkA My two kidneys are yours as the Two Sisters,

$\mathrm{jtH}=\mathrm{j} n=\mathrm{k}$ TAw $\mathrm{m}$ Srtj=j In order to prepare your protection with their magic, $n S p=j n=k$ mHjt $m x x=j$ I will supply you with air from my nose, and exhale the north wind for you from my throat,

msxnt $=j$ rnnt $=j \mathrm{~m} \mathrm{xt}=\mathrm{k}$ My birthing brick and my rnnt are with you,

xnmw=j Hr sqd Dt=k my Khnum forms your body, $\mathrm{Hr} w \mathrm{Hm} \mathrm{n}=\mathrm{k}$ mswt $\mathrm{m}$ nxb wr and repeat birth for you as the Great Lotus Bud.

$n t f=k$ rsj wnj=j n=f wAwt If you desire to breathe the south wind, I jnj $=\mathrm{j} n=\mathrm{k}$ jmntj $\mathrm{r}$ st=f open the way for it;

$\mathrm{sSm}=\mathrm{j} n=k$ jtn $\mathrm{r}$ xny=j I bring you the west wind in its place. app axmw=f Hr Snbt=k I raise the sun for you on my skin, so that its image drifts by on your breast $^{\mathrm{xvi}}$ 
In this stanza, the body of the goddess has all the creative powers, Meskhnet (the birthing bricks), Renenutet (fulfillment) and creation (Khnum). Here the goddess supplies the deceased with all the creative powers that determine his personality, its development and destiny. These powers are owned by every complete person and god. They will be given by Neith to her son King Merenptah. These creative powers will be at Merenptah's disposal. xvii

The association between the licking of the body and the mummification of the deceased occurs also in Papyrus Jumilhac. The papyrus dates back to the Ptolemaic Period, and concerns the legends in the $17^{\text {th }}$ and $18^{\text {th }}$ Nomes of Upper Egypt. The text concerning the licking of the body in Papyrus Jumilhac reads:

$n s b j=f$ awt $j t=f$ wsjr $m$ wabt

$j w=f n m s=f j m=f j w=f r x x=f$
He has licked the body of his father Osiris in the Place of Embalming.

He has bandaged him and enwrapped him as far as his neck. ${ }^{\text {xviii }}$

Here Horus, as the son of the Osiris, licks the body of his father Osiris in the place of Embalming. According to Vandier, the passage identifies a dog with Horus son of Isis, and probably with Anubis. Willems argues that this passage might refer to a man in the shape of a mythical dog rather than a real dog. ${ }^{\text {xix }}$ Here Horus, as a mythical dog, enters the place of embalming of his father Osiris and licks his body. It is not clear how Horus licks the body of his father in the place of embalming. Licking might refer to the kissing of the son to the body of his father Osiris. Horus did not only lick the body of his father, but he also bandaged and enwrapped him as far as his neck.

These ritual actions on the body of the deceased Osiris are taking place in the mythical divine world. Horus, as a ritualist, licks the body of his father Osiris. As in the case of the inscriptions on the coffin of Merenpth mentioned above, the licking of the body of the deceased has a curative and generative power. It will help the deceased, both Osiris and Merenpth, in escaping death and becoming an Ax. In both texts the world of the living, where the ritual is carried out, and the divine world are connected by the recitation which takes place on the body of the deceased Osiris. The priest, who is in the world of the livings, recites incidents that took place in the divine world of the gods. These two spheres are brought together by the power of speech. 


\section{Negative Aspects of Licking the Body}

One of the negative aspects of licking the body occurs in the Pyramid Texts Spell 228, which reads:

Dd mdw xr $\mathrm{Hr}$ r $\mathrm{Hr}$ mA.n $\mathrm{Hr} \mathrm{Hr}$
Recitation:

Face has fallen on face, face has seen face,

prj $\mathrm{nm}$ sAb $\mathrm{km}$ wAD $\mathrm{rs}$ The dappled knife, all black and green, $a m . n=f n=f n s b-n=f$ has emerged and swallowed the one it has licked. ${ }^{\mathrm{xx}}$

The spell is placed in the burial chamber of King Unas and aims at the protection of the king from the bites of snakes and scorpions. When Unas recites the spell, the snake emits it poison and instead of hurting the king, it recoils upon the snake itself. The snake or scorpion is forced to swallow the poison it has ejected by licking. Here again the recitation of the spell will mediate the passage of Unas and help him to avoid the venom of the reptiles in the underworld. ${ }^{\mathrm{xxi}}$

\section{The Licking of the Body as a Punishment}

Licking the body occurs in Coffin Texts spell 335. It is the longest spell in the Egyptian Coffin Texts. It occurs on 35 different coffins from different sites in Egypt. ${ }^{\text {xxii }}$ It is not my aim here to deal with the whole spell, but with certain passages where the licking of the body occurs. A brief interpretation of the spell will be presented in order to give a clear idea of the context in which the licking of the body occurs. Coffin Texts Spell 335 reads:

Dd mdw wsjr pw wDD A speech: Oh Osiris, To whom it was $\mathrm{n}=\mathrm{f}$ HqAt $\mathrm{m}$ nTrw entrusted the rulership of the gods,

Hrw pw n smA tAwj

On that day of the Unification of the Two Lands

m bAH nb r-Dr

In the presence of the Lord of All.

jr smA tAwj dhnt qrs wsjr pw jnjt=f Ra

bA mnx jmj nnjnjswt

Oh potent soul who is in Ninsu,

Ddj kAw drw jsftjw

Who grants powers and expels the 
evildoers,

sSmw n=f wAwt nHH

Dd mdw Ra pw Ds=f

$\mathrm{nHm}=\mathrm{k}$ wj $\mathrm{m}$ a nTr pw TAA bAw

nsb jwtjw

anx m HwAAt

jmj kkw jrj snkt

snDw n=f jmj bAgw
Who shows to him the ways of eternity,

A speech: He is Re himself,

Save me from this god who takes the souls,

And who licks corruption,

And lives on putrefaction,

Who is in darkness and who is in dusk,

Of whom those who are among the languid ones are afraid. ${ }^{\text {xxii }}$

The title of the spell defines its purpose to go out by day (rA n prt $\mathrm{m}$ hrw). ${ }^{\text {xiv }}$ This connects the passage of the deceased with that of the sun god Re, and thus both of them face the obstacles until they are reborn again the next day. ${ }^{\mathrm{xxv}}$

The spell deals with the judgment of the dead and aims to mediate the passage of the deceased into the hereafter. The deceased who is Re goes out into the day after he has escaped death. He has now the free movement of going in and out of the underworld. In order to escape death and proceeds into the underworld, the deceased undergoes a judgment modeled on the judgment of Osiris and Seth. At the end of the judgment, Osiris is justified and wears the wrrt crown as occurs in Coffin Texts Spell 335. During this judgment the unworthy are thrown to a monster, who licks their bodies. For that reason, the deceased begs Osiris not to fall a victim to this monster. It is not clear what is meant here by the licking of the body, but most probably, as the context of the spell refers to, means to be eaten and threaten by a monster that snatches the bodies of the unworthy dead. The verb to lick can also mean to erase or annihilate as one erases ink by licking the papyrus.

\section{Licking a Spell against the Deceased in the Underworld}


In the Middle Kingdom Coffin Texts and New Kingdom Book of the Dead, hostile licking of spells is considered as a threat to the deceased. For instance, in Coffin Texts spell 227 the deceased says:

Hms.n $\mathrm{N}$ pn $\mathrm{m}$ jrt-Hr $\mathrm{m}$ tp This $\mathrm{N}$ sat down with the Eye of xmtw Horus at the Head of the Three, wDa mdw m nTrw m xt DHwtj makt N makt DHwtj m-m=Tn who judge as gods after Thoth. The protection of this $\mathrm{N}$ is the protection of Thoth among you.

$\mathrm{N}$ pn Ax nb Axw Ax jrj $\mathrm{N}$ pn This $\mathrm{N}$ is a spirit and Lord of spirits. A spirit has made this $\mathrm{N}$.

$j w=f w n A x \operatorname{sswn} n N$ wnn=f $\mathrm{He}$ is a spirit who celebrates the monthly festival,

jn N pn jrw Abd smtrwsmdnt and the one who bears witness to the half monthly festival.

jw dbnt jrt $\mathrm{Hr}(\mathrm{r})$ a $\mathrm{n} \mathrm{N}$ pn $\mathrm{m}$ Smsw DHwtj

The circuit of the Eye of Horus is at the hand of this $\mathrm{N}$ in the suite of Thoth.

Jr nTr nb jr nTrt nbt jr Ax nb As for any god, any goddess, any spirit,

jr mwt nb jr mwtt nbt nsw. Tj. or any dead, male or female, who $[\mathrm{fy}]^{\mathrm{xxvi}} \mathrm{rA}=\mathrm{f}$ xft $\mathrm{N}$ pn $\mathrm{m}$ hrw pn

$\mathrm{xr}=\mathrm{fnnmwt}$

HkA jmj n Xt tn n Npn

nsw mrw tpyw rA=f pn

snDw n N mAAw sw

qA N pn pr m tp

jwtj gnnwt=f

Dr.n N xbDj m n aaw sw

n sp wpt $\mathrm{N}$ pn nma m-mrHwj

$\mathrm{N}$ sp sDm=f $\mathrm{m}$ jst $\mathrm{m}$ Dddt nbt

Xft mdw DADAt mj qd=s shall lick his spell against this $\mathrm{N}$ in this day,

He will fall to the execution houses, And to the magic which is in the body of this $\mathrm{N}$,

And to the painful flames which are in his mouth.

Those who see this N, are afraid of him,

For this $\mathrm{N}$ is exalted since he went aloft, since he has no weakness.

$\mathrm{N}$ has expelled the hated one with his hands.

$\mathrm{N}$ has never judged" with partiality between the Rivals,

$\mathrm{N}$ has never heard in the Palace anything that was said, when all the Tribunal spoke,

Hrr rHwj Xr Ddwt n N pn m wDa-mdw

The Rivals were satisfied with what this $\mathrm{N}$ said in judgment, 
n sp wHmt $\mathrm{N}$ pn m pr Hr jrw This $\mathrm{N}$ never repeated a judgment jsft $r=f m d w=s n$ as one who went forth because of those who did evil to him when they spoke.

jr n Nsjsw-pr n (tf)jm m abAt- I have made for him the House of $\mathrm{pr}$ the Eight in the House of the Thirty.

$\mathrm{N}$ pn kA mAat This $\mathrm{N}$ is the Bull of Maat (Justice), $\mathrm{snD} n$ mdw nw $\mathrm{N}$ pn $\mathrm{nhD} \mathrm{n}$ Men respect his voice and dread his kbjt nt $\mathrm{N}$ pn fierceness,

$\mathrm{N}$ pn $\mathrm{mH}-\mathrm{jb} \mathrm{m}$ jst $\mathrm{r}$ gs $\mathrm{kA}$ This $\mathrm{N}$ is confidant of the palace in MAat presence of the Bull of Maat. ${ }^{\text {xxvii }}$

The deceased identifies himself with Thoth and the context of the spell is the judgment of the dead. In this spell the deceased says that he sat down with the Eye of Re at the Head of the Three which is a title of the sun god Re. ${ }^{\text {xviiii }}$ Although he is judged in the tribunal of the gods, he is also a judge. He is assuming the protection of Thoth and plays his role in his monthly festivals. He is an Ax which means that he has passed safely the judgment of the dead. ${ }^{\text {xix }}$ The deceased then threats all the gods, goddesses, spirits, male dead or female dead not to lick their spell against him. If they do so, they will fall to the execution houses, to the flame which comes out from his mouth and to the magic which is in his body.

Licking a spell against the deceased means to testify against him in the judgment of the dead. He is a justified Ax and no single bad word has been said against him in the tribunal of the gods. He is the one who has taken his revenge from the hated one, Seth, the opponent of Osiris. He is the Bull of Maat and the Confidant One who has expelled his enemy and became a glorified spirit. Here uttering or licking a spell could be harmful to the deceased. This means also that the power of the word is important in the glorification and justification of the deceased in the Hall of Maat. The spell also associates licking with the fire as a punishment for those who will lick their spell against the deceased.

The same theme of licking a spell against the deceased in the underworld occurs in Book of the Dead Chapter 149. ${ }^{\mathrm{xxx}}$ In this chapter the deceased says:

jr nTr nb mwt nb

$\mathrm{Nsb}=\mathrm{f} \mathrm{rA}=\mathrm{f}$ xft=j m hrw pn
As for any god and every dead,

Who shall lick off his spell against me in this day, 


\section{Conclusion}

In this paper the licking of the body has been dealt with in the funerary texts of ancient Egypt. Other usages of licking the body, as

in magical and healing texts, have been dealt with by Ritner. ${ }^{\text {xxii }}$ The licking of the body in ancient Egyptian funerary texts differs from a context to another. It might refer to the simple act of licking the body of a young calf by his mother as in the texts of the queen Hatshepsut. When used in a funerary context, this licking refers to the saliva that comes out from the mouth of the mother, when she licks the body of her son and restores his life. In the inscription of the coffin of Merenptah, Neith licks the body of the king and the saliva that comes out from her mouth has a healing power that restores something that has been lost at the death. It is a symbol of rebirth. The licking restores the body of the deceased king Merenpth who has collapsed at death. The licking of the body occurs also in the context of mummification where Horus licks the body of his deceased father Osiris as occurs in Papyrus Jumilhac.

The negative aspect of licking the body is referred to when the deceased is frightened that his body is licked by a monster in the course of the judgment of the dead. The monster that licks the unworthy dead is pictured as a dog with human skin and face of a dog. This licking is also envisaged as an injury that can be caused to the deceased by Seth during the judgment of the dead. This licking can be interpreted as a total destruction to the body of the deceased Osiris.

Licking of a spell means to say or bears witness against the deceased in the judgment of the dead. The punishment of those who will lick their spell against the deceased will be falling to the depths of the underworld or to be thrown to the houses of executions.

\section{Bibliography}

De Buck, A., The Ancient Egyptian Coffin Texts.7 vols. Chicago, 1935-1961.

Allen, J. P., The Ancient Egyptian Pyramid Texts (Writings from the Ancient World 23). Atlanta, 2005. 
Assmann, J. "Die Inschrift auf dem äußeren Sarkophagdeckel des Merenptah", MDAIK 28a (1972), 47-73:

-_Neithsprichtals Mutter und Sarg: Interpretation und metrisch Analyse der Sargdeckl Inschrift des Merenptah', MDAIK 28b (1972), 115-139.

Assmann, J., Death and Salvation in Ancient Egypt, translated from German by D. Lorton. Ithaca and London, 2005.

Assmann, J., M. Bommas and A. Kucharek, Altägyptische Totenliturgien, vol. II, Totenliturgien und Totensprüche in Grabinschriften des Neuen Reiches, Supplemente zu den Schriften der Heidelberger Akademie der Wissenschaften, Philosophischhistorische Klasse 17, Heidelberg, 2005.

, Altägyptische Totenliturgien, vol. III, Osirisliturgien in Papyri der Spätzeit, Supplemente zu den Schriften der Heidelberger Akademie der Wissenschaften, Philosophisch-historische Klasse 20, Heidelberg, 2008.

Billing, N. Nut: The Goddess of Life in Text and Iconography.Uppsala, 2002.

Jürgens, P., 'Zum überlieferungs geschichtliche nZusammenhang der Sargtext sprüche 335 und 397', SAK 29 (2001), 111-138.

Lapp, G, The Papyrus of $\mathrm{Nu}$, Catalogue of the Books of the Dead in the British Museum I, London, 1997.

Lüscher, B., TotenbuchSpruch 149/150, TotenbuchtexteSynoptischeTextausgabenach Quellen des Neuen Reiches 6, Basel, 2010.

Naville, E. 1901: Temple of Deir El-Bahri IV, London , 1901.

Ritenr, R. K., The Mechanics of Ancient Egyptian Magical Practice (SAOC 54).Chicago, 1993.

Sethe K. Urkunden der 18 Dynastie IV, Band I. Leipzig, 1906. 1908-1922.

Shalomi-Hen, R., Classifying the Divine: Determinatives and Categorisations in CT 335 and BD 17 (GOF IV/38). Wiesbaden, 2000.

Smith, M., Following Osiris: Perspectives on the Osirian Afterlife from Four Millennia, Oxford, 2017. 
Stadler, M., Weiser und Wesir: StudienzuVorkommen, Rolle und Wesen des GottesThotimägyptischenTotenbuch (OrientalischeReligionen in der Antike: Ägypten, Israel, Alter Orient I/ Oriental religions in Antiquity: Egypt, Israel, Ancient Near East 1. 2009.

Vandier, J., Papyrus Jumilhac. Paris, 1961.

Willems, H., The Coffin of Heqata (Cairo JDE 36418): A Case Study of Egyptian Funerary Culture of Early Middle Kingdom (OLA 70). Leuven, 1996.

${ }^{1}$ Assmann, J. "Die Inschrift auf dem äußeren Sarkophagdeckel des Merenptah", MDAIK 28a (1972), 47-73: "Neithsprichtals Mutter und Sarg: Interpretation und metrisch Analyse der Sargdeckl Inschrift des Merenptah', MDAIK 28b (1972), 115-139.

${ }^{1}$ Assmann, J., M. Bommas and A. Kucharek, Altägyptische Totenliturgien, vol. II, Totenliturgien und Totensprüche in Grabinschriften des Neuen Reiches, Supplemente zu den Schriften der Heidelberger Akademie der Wissenschaften, Philosophischhistorische Klasse 17, Heidelberg, 2005, 50-57.

${ }^{1}$ Smith, M., Following Osiris: Perspectives on the Osirian Afterlife from Four Millennia, Oxford, 2017, 110110.

${ }^{1}$ Assmann et al, Totenliturgien II, 9.

${ }^{1}$ Assmann, J., M. Bommas, A. Kucharek, Altägyptische

Totenliturgien, vol. III, Osirisliturgien in Papyri der Spätzeit,

Supplemente zu den Schriften der Heidelberger Akademie der

Wissenschaften, Philosophisch-historische Klasse 20, Heidelberg, 57.

${ }^{1}$ Assmann, Totenliturgien, 82.

${ }^{1}$ Assmann MDAIK 28a (1972), 47ff; the translation uses

Assmann,J., Death and Salvation in Ancient Egypt, translated from German by D. Lorton. Ithaca and London, 165-166.

${ }^{1}$ For the speeches on of the sky goddess Nut on the New Kingdom coffins, see Billing, N. Nut: The Goddess of Life in Text and Iconography. Uppsala, 2002, 293-308.

${ }^{1}$ Assmann MDAIK 28a (1972), 48ff.

${ }^{1}$ Assmann Death and Salvation, 39-45.

${ }^{1}$ Sethe, K., Die altägyptischen Pyramidentexte, 3 vols.Hildesheim, 1908-1922, 89c-98b (spell 166); Allen, J. P., The Ancient Egyptian 
Pyramid Texts (Writings from the Ancient World 23). Atlanta, 2005: 27; The same theme occurs also in Coffin Texts spell 936.

${ }^{1}$ Assmann, Death and Salvation, 357; Assmann 2003: 8.

${ }^{1}$ Sethe K. Urkunden der 18 Dynastie IV, Band I. Leipzig, 1906:

Band I: 239, 11. 7-9; Naville, E. 1901: Temple of Deir El-Bahri IV, London, 1901, Pl. XCIV.

${ }^{1}$ Sethe, Urkunden IV, Band I, 238, II, 1-4.

1 -De Buck, The Ancient Egyptian Coffin Texts. 7 vols. Chicago, 1935-1961, vol. VII, 305b-306a.

${ }^{1}$ Assmann et al, Totenliturgein II, 51-52; Assmann 2005:165-166.

${ }^{1}$ Assmann, Death and Salvation, 164.

${ }^{1}$ Vandier, J., Papyrus Jumilhac. Paris, 1961: Pl. XVI, lines 4-5. The translation is that of Willems, H., The Coffin of Heqata (Cairo JDE 36418): A Case Study of Egyptian Funerary Culture of Early Middle Kingdom (OLA 70). Leuven, 276, n. 1591.

${ }^{1}$ Willems, Heqata, 276, n. 1591.

${ }^{1}$ Sethe, Pyr. 228a-228b (Spell 228); Allen, Pyramid Texts, 17.

${ }^{1}$ Ritenr, R. K., The Mechanics of Ancient Egyptian Magical Practice (SAOC 54).Chicago, 1993, 97.

${ }^{1}$ On the historical transmission of Coffin Texts Spell335, see Jürgens, P., 'Zum überlieferungs geschichtliche nZusammenhang der Sargtext sprüche 335 und 397', SAK 29 (2001), 111-138.

${ }^{1}$ De Buck, Coffin Texts, vol. IV, 317c-320d.

${ }^{1}$ De Buck, Coffin Texts, vol. IV, 185a (CT Spell 335).

1 Shalomi-Hen, R., Classifying the Divine: Determinatives and Categorisations in CT 335 and BD 17 (GOF IV/38). Wiesbaden, 2000: 13.

${ }^{1}$ Defective writing of nsb to lick, Ritenr, Mechanism, 98, n. 480.

${ }^{1}$ De Buck, Coffin Texts, vol. IV, 18b-21f.

${ }^{1}$ WB III: 283.12.

${ }^{1}$ For the roles played by the deceased as Thoth, see Stadler, M., Weiser und Wesir: StudienzuVorkommen, Rolle und Wesen des GottesThotimägyptischenTotenbuch (OrientalischeReligionen in der 
Minia Journal of Tourism and Hospitality Research Vol. (8), No. (1), December 2019

Antike: Ägypten, Israel, Alter Orient I/ Oriental religions in Antiquity: Egypt, Israel, Ancient Near East 1. 2009.

${ }^{1}$ For Book of the Dead 149, see Lüscher, TotenbuchSpruch 149/150, Totenbuchtexte-SynoptischeTextausgabenach Quellen des Neuen Reiches 6, Basel, 2010.

${ }^{1}$ Lapp, G, The Papyrus of Nu, Catalogue of the Books of the Dead in the British Museum I, London, 1997, Chapter 149, Pls. 83-85.

${ }^{1}$ Ritner, Mechanism, 92-102. 
Minia Journal of Tourism and Hospitality Research Vol. (8), No. (1), December 2019 